\title{
Wildfire Management in the Tain II Forest Reserve of Ghana: An Evaluation of Community Participation
}

\author{
Enoch Akwasi Kosoe1, Issaka Kanton Osumanu1 ${ }^{*}$, Victor Rex Barnes ${ }^{2}$ \\ ${ }^{1}$ Department of Environment and Resource Studies, University for Development Studies, Wa, Ghana \\ ${ }^{2}$ Faculty of Renewable Natural Resources, Kwame Nkrumah University of Science and Technology, Kumasi, \\ Ghana \\ Email: ${ }^{*}$ kosumanu@uds.edu.gh
}

Received 11 October 2015; accepted 24 October 2015; published 30 October 2015

Copyright (C) 2015 by authors and OALib.

This work is licensed under the Creative Commons Attribution International License (CC BY).

http://creativecommons.org/licenses/by/4.0/

(c) (i) Open Access

\begin{abstract}
Until 1983 uncontrolled wildfires were uncommon, especially in the forest zones of Ghana. Unfortunately early efforts at curbing wildfires did not place emphasis on stakeholder management. This weakness has constrained wildfire management as a result of weak coordination among stakeholders in the management of wildfire. But an essential element for the success of wildfire management is the active involvement of all stakeholders. This study was conducted to assess the role of stakeholders in wildfire management in the Tain II Forest Reserve in the Brong Ahafo Region of Ghana. The study relied on both qualitative and quantitative approaches using household questionnaires as its primary data collection instrument. The study reveals that stakeholders occasionally participated in wildfire management planning, implementation and monitoring activities at the community level. This assertion was confirmed by the index of participation indicating that stakeholders were occasionally involved in wildfire management regarding planning (0.59), implementation (0.60) and monitoring (0.56). Also, empirical results show that the absence of incentives and lack of insurance serve as disincentives for effective functioning of wildfire squad volunteers around the Tain II forest reserve. The study concludes that the success, or otherwise, of wildfire management interventions, to a large extent, depends on the degree of involvement of stakeholders and the support given to them.
\end{abstract}

\section{Keywords}

Wildfire Management, Stakeholder Participation, Volunteer Squads, Tain II Forest Reserve, Ghana

Subject Areas: Natural Geography

\footnotetext{
${ }^{*}$ Corresponding author.
}

How to cite this paper: Kosoe, E.A., Osumanu, I.K. and Barnes, V.R. (2015) Wildfire Management in the Tain II Forest Reserve of Ghana: An Evaluation of Community Participation. Open Access Library Journal, 2: e1964. 


\section{Introduction}

In Ghana, it has been estimated that the total land prone to wildfire annually ranges from 30\% in the high forest and transitional zones to over $90 \%$ in the dry northern savannah zones [1]. As the number of forest fires appears to increase, conventional suppression measures have increasingly come under question. Instead of alleviating forest fire problems, these measures have not solved the problem, and, in some countries, the scale and magnitude of forest fires have increased [2]. Thus, many agencies have started exploring more proactive approaches in combating fires, but many policy makers and development workers are debating whether communities are capable of managing forest fires. However, it is increasingly accepted by many fire experts that the community is the key to the survival of forests through integrating indigenous knowledge, conservation values and sustainable livelihoods [3]. As a result, Community-Based Fire Management (CBFiM) has emerged as a new and increasingly adaptive mechanism for working with and managing fire [4] [5]. The catalysts behind CBFiM approaches are indigenous land and/or use rights, as well as the right to use fire as a management tool [6]-[8]. Community-based fire management case studies show a shift in direction: a movement away from centralized and statedriven fire management towards decentralized and mainly community-based management. Case studies indicate that communities have a clear role in wildfire management-in some cases with full responsibility and in others with joint responsibility as co-owners and co-managers of forest resources [9].

In many parts of the world, local communities are often blamed for what are considered "harmful forest fires". This view often encourages fire and forest management institutions to perceive local communities as part of the problem, and certainly not part of the solution [6] [7] [10]. The human dimensions of fire and the positive social and ecological benefits of smaller prescribed and managed fires have been largely ignored [4]. But in Ghana, the 2006 National Wildfire Management Policy has recognized the crucial role communities and other stakeholders can play in the sustainable management of natural resources though this is not backed by any legislative instrument to compel implementing agencies to do so [11]. Indeed, the policy did not empower traditional authorities and communities to play a key role in its enforcement [1] [12].

A review of existing literature shows limited knowledge on effectiveness of community stakeholder participation in wildfire management in Ghana. Although, extensive research work has been done on the causes and effects of wildfires, the role of fire in farming systems, socio-economic effects of wildfire, effects of uncontrolled and controlled burning among others, not much work has been done on stakeholder participation in wildfire management. Also, much has not been done in the area of the effectiveness of stakeholders' participation regarding fire initiative programmes carried out in rural communities in Ghana. It is in this light that this study is carried out to assess the role of stakeholders in wildfire management in the Tain II Forest Reserve in the Brong Ahafo Region of Ghana. The study examines whether stakeholders are actually involved in fire management regarding planning/decision making, implementation of activities, logistics and finances, monitoring of community fire management. It would also seek community members' opinion of who these stakeholders are and whether they are effective.

\section{Stakeholder Participation in Wildfire Management}

Though information on involving communities in wildfire management is still scarce, widely scattered and only slowly evolving, the involvement of all stakeholders can play substantial role in forest fires management [13]. A prerequisite for the success of fire management is the active involvement of all stakeholders and raising their awareness [14]. Integration of traditional approaches into forest fire management systems will need a concerted effort by all stakeholders to build constructive partnerships that recognize the importance of attitudes toward fire, roles in decision making and securing incentives for balance fire management [4]. Furthermore, fire management would only be successful if stakeholders agree on a distribution of responsibilities, decision making, power and resources [15]. But Fire Fight West Africa [16] concluded that if harmful forest fire is to be contained then fire related behaviour of a range of stakeholders must be addressed and that attention has to be focused on policy reform and the removal of pervasive economic incentives that encourage stakeholders to use fire irresponsibly. High levels of public participation are often cited as central components of an effective planning process for ecosystem management and environmental planning in general [17]. Scholars argue that because ecosystem management is, by definition, a trans-boundary, multiparty issue, the participation of key stakeholders is widely viewed as the single most important element of a successful outcome [18]-[23]. Again, including stakeholders in decision making processes help build a sense of ownership and ensures that all interest is reflected [24] [25]. 
Moreover, it has been opined that co-management agreements between local people, stakeholders and government agencies offers substantial promise as a way of dealing with natural resources based conflicts [26]. These collaborative natural resources management arrangement can also foster a sense of community empowerment in decision making and benefit sharing [26]. Added to this, stakeholder participation goes beyond ownership to contribution of resources, knowledge, time, personnel, funding, and technical experts which enhances effective management by allowing for expansive data collection, better monitoring of programmes and regular planned updates [17]. Although stakeholders hold different interests, the fundamental assumption is that sharing authority and decision making enhance the process of resource management, making it more responsive to a range of needs [27]. But others are of the view that the underlying assumption of stakeholder participation is that these groups have valuable knowledge and resources to contribute to management of natural resources [17].

During the 1980s and 1990s, several technical co-operation projects implemented on fire dealt directly with national institutions responsible for the prevention and control of forest fires. Local people, who use fire and are affected by it, were not involved in project activities. There was little or no recognition of local people as important actors and stakeholders [15]. In Ghana, Fire Fight West African [16] identified lack of inter-agency working relationship and little stakeholder participation in fire management. While theorists and practitioners consistently call for increased participation in ecosystem management and environmental planning in general, only few studies have empirically tested the assumption that community representation and stakeholder participation during the planning process will lead to stronger and more durable management [28]. The driving trend toward increased participation of local people and stakeholders in management is based on greater decentralization and devolution which rose from the realization that central governments often lack the capacity to manage fires effectively and also advocating increased partnership with local people, recognizing that their own forest management techniques are inadequate [13].

\section{Wildfire Management Institutions in Ghana}

In Ghana there are a number of institutions and/or agencies involved in fire management (fire prevention and control). These agencies, among others, are mandated under law(s) to perform such roles whilst others play collaborative roles. The agencies involved in fire management include: the Ghana National Fire Service (GNFS); Forestry Commission (FC)-Wildlife Division (WD); Environmental Protection Agency (EPA); National Disaster Management Organization (NADMO); Forest Research Institute of Ghana; and the District Assemblies. The Ghana National Fire Service (GNFS) under the PNDC law 229 is mandated to train fire volunteers. The law gave fire volunteers the responsibility to implement byelaws on fire drawn by District Assembly [28]. However, the law (PNDC Law 229) did not give any legal protection, health care, insurance and incentives to fire volunteers. The GNFS organizes each year (November to March) Anti-Bushfires Campaigns through public education on the radio, the use mobile vans and visits to communities. The Forest Services Division (FSD) and Wildlife Division (WD) under the Forestry Commission are responsible for fire management. The FSD is responsible for the implementation of the National Forest Policy. Recently, the FSD has implemented the fire management project in the transitional zone and focused on developing and implementing effective means of preventing and controlling wildfires in fire prone forest areas with local communities' involvement [27]. On the other hand, the WD is exempted by the law (PNDC Law 229) to use fire for the management of reserves and parks. It carries out early burning in the savanna and transitional zones prior to the dry season [27]. Also, NADMO was empowered by law (Act 517, 1996) to be responsible for the management of areas affected by disasters and similar emergencies, for the rehabilitation of persons affected by disasters and to provide for related matters. The Act also mandated NADMO to set up sub-committees, which are technical in nature, to come out with plans for the management of specific types of disasters, which the Wildfires or Lightening Sub-committee is part. NADMO is mandated not only to manage disaster, among which wildfire is one, but also to identify the various hazard types, map them and plan to prevent those which are man-made and to mitigate their effects [29]. NADMO also conducts public education on wildfires through the use of radio, seminars, workshops and durbars [30].

The Environmental Protection Agency (EPA), which was formally known as Environmental Protection Council (EPC), was established by a decree in 1974 due to the devastating effects of wildfire nationwide [31]. The EPC played a major role in developing fire prevention and control programmes in Ghana. It further collaborated with the Forestry Commission, GNFS and Meteorological Services Division to carry out fire prevent educational campaigns through workshops and conferences [30]. However, since the inception of EPA by Act 
470 of 1994 its focus has changed from a direct role in fire prevention programmes to enforcing and regulating environment laws (EPA, 1996). District Assemblies are obliged by PNDC Law 229 to establish Bushfire Control Sub-Committees of the Executive Committees of the District Assemblies. The Bushfire Control Subcommittees are empowered to draw bye-laws to ensure adequate control of wildfires in the districts.

\section{Study Area: The Tain II Forest Reserve}

Tain II Forest Reserve (Figure 1) forms part of the dry semi-deciduous fire zone (DSFZ) [32] in Ghana. The bulk of the reserve is a transitional high forest with areas of derived savannah grassland intruding into the forest along parts of the external boundary. The Tain II Forest Reserve, which was established in 1934, covered 509.20 $\mathrm{km}^{2}$. By the year 1986, the area of forest cover was $499.10 \mathrm{~km}^{2}$ whiles that of 1991 forest cover was $451.37 \mathrm{~km}^{2}$. In the year 2000, the forest cover was $108.87 \mathrm{~km}^{2}$ while the forest cover for 2007 was $87.53 \mathrm{~km}^{2}$. The following are percentage changes of forest cover from 1986 to 2007. The possible causes of the high percentage changes in the forest cover have been attributed mainly to the annual wildfires occurrences in and around the forest reserve, increasing population growth with its associated increase in land use activities, uncontrolled logging, irresponsible farming practices and erratic rainfall patterns [11]. From Figure 2, it is evident that forest cover of the project catchment (Tain II Forest Reserve) has improved slightly from $17.71 \%$ to $22.05 \%$ within the course of the project (APERL) (from 2007-2013) due to plantation activities (establishment of woodlots). Another significant change of interest is the increase in Agricultural activities. Agricultural Activities doubled from 11.52\% (2195.46 hectares) to $22.17 \%$ (4224.9 hectares); Forest changed from $17.71 \%$ (3375.54 hectares) to $22.05 \%$ (4202.22 hectares); Open forest changed from 41.25\% (7861.41 hectares) to 42.18\% (8037.96 hectares); Grass land changed from $26.49 \%$ (5047.47 hectares) to $9.55 \%$ (1819.99 hectares) and Built-Up area changed from 3.02\% (575.78 hectares) to $4.04 \%$ (770.59 hectares).

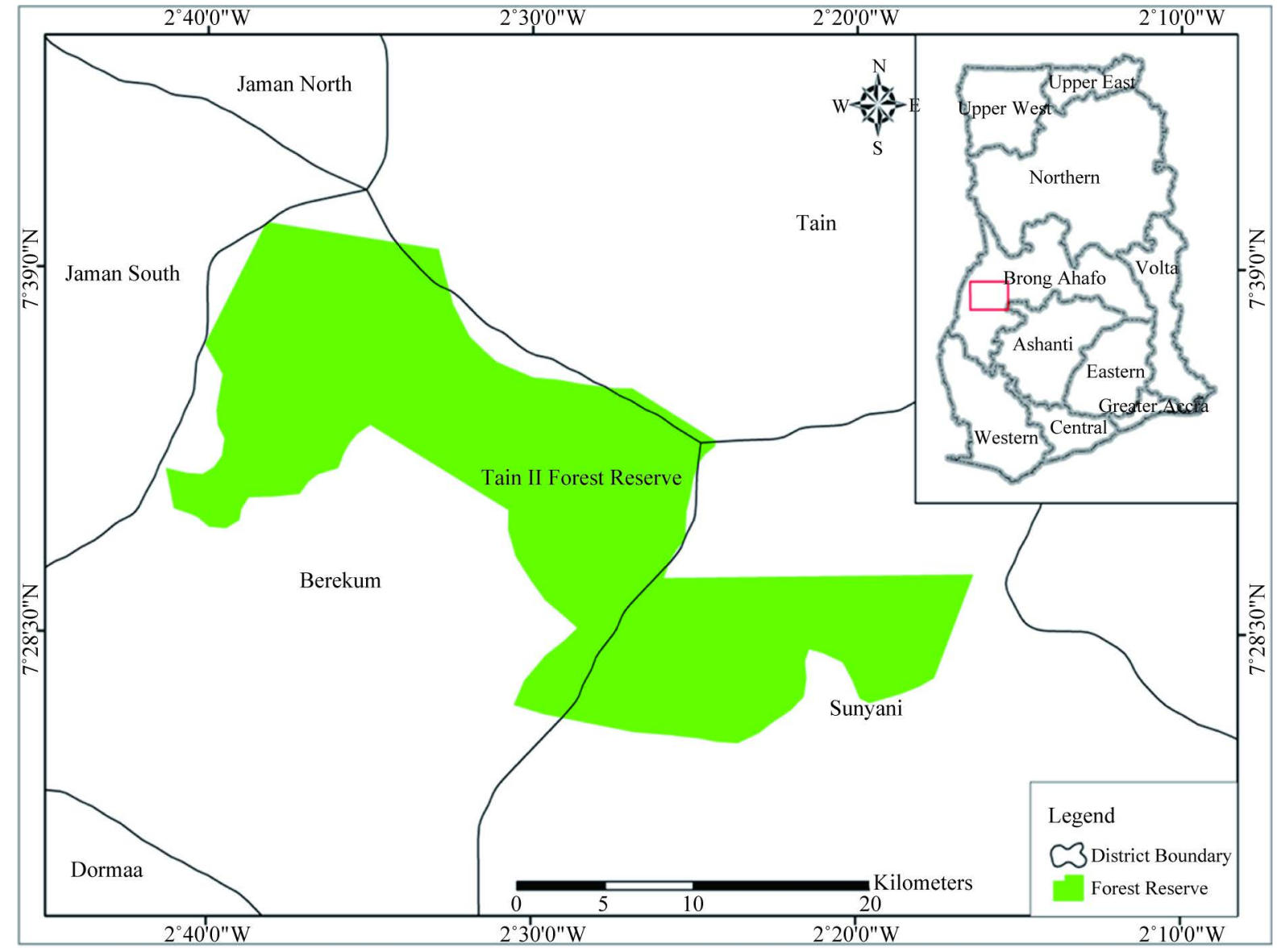

Figure 1. A map of Tain II forest reserve. 


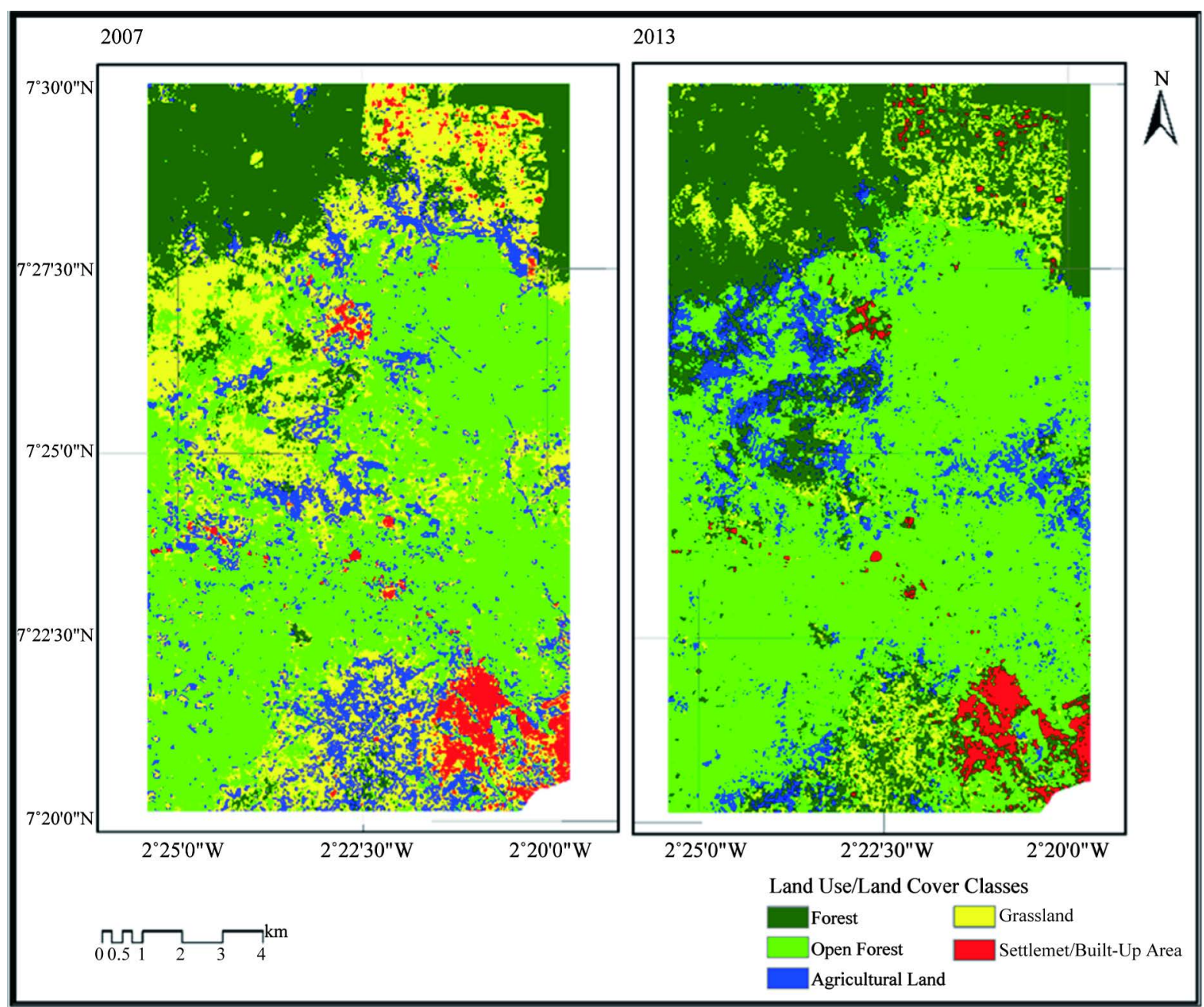

Figure 2. Satellite imageries of Tain II forest reserve cover.

\section{Methodology}

The study generated first-hand information from the field apart from documented sources it relied upon. Both qualitative and quantitative approaches were used taking into consideration the data demands. Household questionnaires were used as the primary data collection instrument. This approach is deemed appropriate when the object of the research is to explore attitudes or reactions of a group or community in response to some commonly experienced aspects of their environment. Through such interactive discourse, participants are able to offer insights on the perspective of the enterprise, revealing clues to the social contexts that shape their opinions. In the household survey, questionnaires were administered to household heads and, in their absence, the available spouse was used, preferably a woman if the household head is a man. The questions for the interviews were open-ended to allow participants express their views more freely than in a structured questionnaire. Also, 24 questionnaires were administered to five institutions involved in wildfire management, i.e., GNFS, NADMO, FSD, Ministry of Food and Agriculture (MOFA), and the Brong Ahofo Regional Forestry Commission. Focus group discussions were held with Fire Volunteer Squads and Staff of the Department of Rural Fire Division of the GNFS separately. The focus group discussions created a favourable condition for in-depth sharing of knowledge and insights on stakeholder participation in wildfire management around the Tain II Forest Reserve.

Two sampling techniques were used for the selection of participants for the study. Purposive sampling technique was used to select key informants from five government institutions and five communities for the investigation. Simple random sampling technique was used to select households from the five study communities for questionnaire administration. In all, a total of 438 respondents were interviewed from both households and fire 
volunteers as follows: Fiapre-155; Dumesua-134; Adoe-54; Motoase-29 and Ayakomaso-66. Quantitative data generated was analysed using descriptive statistics with the aid of Statistical Package for Social Scientists (SPSS). The analyses were done both comparatively and descriptively using frequencies and percentages. To measure stakeholder participation in community fire management, index of participation were calculated based on involvement in fire management planning, implementation and monitoring. A 5-point scale comprising: always, often, occasionally, rarely and never were used to measure the degree of participation. Index of participation [33] was used to calculate the participation indexes. The Index of Participation values are interpreted on a scale of 0 1 ; where zero means stakeholders have no chance of participating and 1 means always participating. Increase in values from 0 - 1 implies increase in participation level of the stakeholder group with respect to the specific forest resources management activity. The qualitative data collected from the focus group discussions on local people's perceptions of stakeholder participation in wildfire management was analyzed using content analysis based on themes and topics.

\section{Results and Discussion}

The study indentified the following stakeholders in the management of wildfires in the Tain II Forest Reserve: fire volunteer squads; traditional authorities (Chief/Elders); fuel-wood collectors; hunters; opinion leaders; Unit Committee Members/Assembly Persons; Forestry Commission; youth groups and environmental clubs; and GNFS. In order to ascertain the opinion of households on stakeholder participation in wildfire management, the study sought their views on the following specific issues of wildfire management activities (wildfire planning, implementation, and monitoring). With regard to planning to combat wildfire, the following were considered: logistic supply, finances and technical training. Table 1 indicates respondents' views of stakeholders' participation on wildfire planning. Of the 438 respondents interviewed, 230 (53\%) respondents indicated that stakeholders occasionally participated in wildfire management planning activities at the community level while 28 (6\%) stated that stakeholders never participated in fire management planning.

The assertion made by households that stakeholders occasionally involved in wildfire management in the communities is further confirmed by their responses regarding logistics supply for wildfire management in the communities. A total of 226 (51.6\%) respondents stated that stakeholders do not take part in decisions regarding logistics while 96 (22.0\%) respondents stated that stakeholders' are involved. But 116 (26.4\%) respondents do not know whether stakeholders are involved. Also, 251 (57.3\%) respondents said stakeholders are not involved in fire management finances while 60 (13.7\%) disagreed and 127 (29\%) could not tell whether stakeholders are involved. In addition, 209 (47.7\%) respondents point out that stakeholders are not involved in technical decisions while 165 (37.7\%) respondents indicated that stakeholders are involved. But 64 (14.6\%) respondents could not tell whether stakeholders are involved in technical support in fire management in the study communities. With regards to wildfire implementation activities in the communities, 230 (53\%) respondents stated that stakeholders occasionally did participate in wildfire implementation activities while 28 (6\%) expressed the view that stakeholders never participated in fire implementation (Table 2). They mention that fire volunteers occasionally partake in the annual wildfire sensitization campaigns and also receive some demonstration training on how to create wildfire belts and combat wildfire from the Department of Rural Fire of GNFS.

Furthermore, 266 (61\%) of the respondents interviewed indicated that stakeholders occasionally participated in fire monitoring in the communities while 16 (4\%) specified that stakeholders "always participated" in fire monitoring in the communities (Table 3).

Table 1. Stakeholders participation in wildfire management planning around the Tain II forest reserve.

\begin{tabular}{ccccccccc}
\hline Respondents responses on: & Communities & A & O & Oc & R & N & Total \\
\hline & Adoe & 3 & 8 & 30 & 10 & 3 & 54 \\
How regular do stakeholders participate in wildfire & Motoase & 0 & 0 & 26 & 3 & 0 & 29 \\
management planning at the community level? & Fiapre & 11 & 14 & 66 & 39 & 25 & 155 \\
& Dumesua & 16 & 21 & 70 & 27 & 0 & 134 \\
& Ayakomaso & 3 & 21 & 38 & 4 & 0 & 66 \\
& Total & 33 & 64 & 230 & 83 & 28 & 438 \\
\hline
\end{tabular}

A—Always; O—Often; Oc—Occasionally; R—Rarely; N—Never. 
Table 2. Stakeholders participation in wildfire management implementation around the Tain II forest reserve.

\begin{tabular}{|c|c|c|c|c|c|c|c|}
\hline Respondents responses on: & Communities & A & $\mathrm{O}$ & Oc & $\mathrm{R}$ & $\mathrm{N}$ & Total \\
\hline \multirow{6}{*}{$\begin{array}{l}\text { How regular do stakeholders participate in fire } \\
\text { management implementation at the community level? }\end{array}$} & Adoe & 3 & 8 & 30 & 10 & 3 & 54 \\
\hline & Motoase & 0 & 0 & 26 & 3 & 0 & 29 \\
\hline & Fiapre & 11 & 14 & 66 & 39 & 25 & 155 \\
\hline & Dumesua & 16 & 21 & 70 & 27 & 0 & 134 \\
\hline & Ayakomaso & 3 & 21 & 38 & 4 & 0 & 66 \\
\hline & Total & 33 & 64 & 230 & 83 & 28 & 438 \\
\hline
\end{tabular}

A-Always; O_Often; Oc-Occasionally; R-Rarely; N-Never.

Table 3. Stakeholders participation in wildfire monitoring around the Tain II forest reserve.

\begin{tabular}{|c|c|c|c|c|c|c|c|}
\hline Respondents responses on: & Communities & A & $\mathrm{O}$ & Oc & $\mathrm{R}$ & $\mathrm{N}$ & Total \\
\hline \multirow{6}{*}{$\begin{array}{l}\text { How regular do stakeholders participate } \\
\text { in fire monitoring at the community level? }\end{array}$} & Adoe & 0 & 9 & 31 & 11 & 3 & 54 \\
\hline & Motoase & 0 & 0 & 26 & 3 & 0 & 29 \\
\hline & Fiapre & 4 & 13 & 66 & 44 & 28 & 155 \\
\hline & Dumesua & 12 & 3 & 97 & 22 & 0 & 134 \\
\hline & Ayakomaso & 0 & 17 & 46 & 3 & 0 & 66 \\
\hline & Total & 16 & 42 & 266 & 83 & 31 & 438 \\
\hline
\end{tabular}

A-Always; O_Often; Oc_-Occasionally; R—Rarely; N-Never.

With regards to wildfire monitoring, the households indicated that it is only the fire volunteer squads who does it. According to the households, the fire volunteer squads visit farms to teach farmers how to create fire belts and what to do in an event of accidental wildfire. The study revealed that GNFS is not able to monitor the activities of the fire volunteers and neither do the fire volunteers are able to give feedback to GNFS due to financial constraints. The study discovered that wildfire fighting equipment are not available and, even where these wildfire fighting equipment are available, they are not enough to be distributed among wildfire volunteers. This, according to community members, does not allow fire volunteers to give off their best in fighting wildfires. In a discussion with some staff of GNFS, it was further stressed that the Department of Rural Fire and fire volunteers are not equipped for effective wildfire management. The department is further under-staffed and has limited logistics for their educational campaigns and training of communities. Although GNFS get some support from the District Assembly and Regional Coordinating Council during the annual National Farmers' Day Celebration and the annual dry season campaign, which is also done during the Farmer's Day celebration, these are only isolated cases and often the support is given on one-off basis.

To further ascertain the views expressed by households, a general question was asked whether stakeholders are actively involved in wildfire management around the Tain II Forest Reserve. The households indicated that stakeholders are not actively involved in wildfire management in their communities. The results revealed that 272 (62\%) respondents agreed that stakeholders are not actively involved in wildfire management while 146 (33\%) disagreed. But 20 (5\%) respondents do not know whether stakeholders are involved in fire management or not. But these views of the households were contested by the five institutions interviewed. Not surprisingly, the index of participation calculated from the study revealed that stakeholders participated in wildfire management regarding planning, implementation and monitoring occasionally in the study communities. The index of participation for stakeholders regarding planning, implementation and monitoring were $0.59,0.60$ and 0.56 respectively. This was confirmed by the five institutions index of participation regarding planning, implementation and monitoring. The calculated indexes of participation for stakeholders from the five institutions are 0.62, 0.67 and 0.60 respectively for fire management planning, implementation and monitoring.

In a focus group discussion, wildfire volunteer leaders indicated that even if they are involved they do so oc- 
casionally in wildfire management decision making. It was observed that stakeholders, such as GNFS and FSD of the Forestry Commission occasionally train and equip the fire volunteers in preparation for the dry session when fires are rampant. It was also gathered from the group discussions that wildfire management was carried out by various government agencies which, in the opinion of the study communities, does not help the current situation of annual wildfires because it brings with it conflicting implementation strategies and programmes. This is confirmed by FAO [34] [35] who states from its empirical observation that wildfire prevention and control is hampered by unclear lines of institutional responsibilities and by conflicting policies and regulations. This view is in line with Fire Fight West African [16] who is of the opionion that there is the lack of inter-agency working relationships and little stakeholder participation in wildfire management in Ghana. The lack of active or frequent participation of stakeholders might be contributing to the wildfire incidence every year. This view is reiterated by the Ghana National Wildfire Policy [1] indicating that national efforts have constrained wildfire management at all levels of governance as a result of weak coordination among stakeholders on the issues of wildfire management. It is an indication that stakeholders' knowledge and resources, which has been stated as the underlying assumption of stakeholder participation [17], will not be brought to the fore in fire management around the Tain II Reserve. Also, the lack of involvement of stakeholders in wildfire management will not bring about the sharing of authority and decision making, which has been identified as the fundamental assumption for stakeholder participation [36]. This will not enhance the processes of wildfire management, making it more responsive to a range of community as well as stakeholder needs. Based on this, the Ghana National Wildfire Policy [1] has called for the institutionalization of participatory approaches in wildfire management at all levels and empowering traditional authorities and community leaders to take full responsibility for the prevention and control of wildfires at community and village levels.

An interesting outcome, generated from the study, is that stakeholders at the community level are not given incentives for their participation in wildfire management. The incentives being mentioned here refer to monthly stipends to support their up keep and medical bills. For instance, there are no insurance packages for wildfire fighters in case of injuries and/or deaths regarding fighting wildfires. This explains their reluctance to actively participate in wildfire fighting whenever there is wildfires outbreak around the Tain II Forest Reserve. This was confirmed in separate group discussions with opinion leaders in the five communities, GNFS and the District Forestry Services Division. However, the Ghana National Wildfire Policy [1] called for the establishment of a National Wildfire Fund and a district based insurance scheme to ensure sustainable participation of all stakeholders in wildfire management activities. Also, the policy proposes the institution of incentives, rewards and benefit sharing schemes for communities, individuals and institutions that distinguish themselves in wildfire management. Studies have shown that incentives are important ingredients for successful community-based fire management [4]. It has further been noted that focus should be on people and organizational structures rather than equipment or legal contracts [4]. Many studies conducted in separate places also revealed that the underlying reason for local communities' failure to control wildfires is not lack of awareness or carelessness but rather lack of incentives to protect forest resources [37]-[42].

A major question to ask is if stakeholders are not involved in community wildfire management on the whole, how then can they lay claim to incentives for themselves for partaking in community fire management processes? The supposedly lack of incentives for stakeholders to participate in wildfire management might account for the low participation of stakeholders in wildfire management decisions regarding logistic, finances and technical support in the study communities. Ganz and Moore [4] are of the view that the existence of incentives is a factor that appears to intimately associate with sense of ownership. The provision of some sort of incentives, from government official sources or traditionally, appears to be a key element in the active participation of communities or stakeholders in wildfire management [4]. The question raised by Fire Fight West African [16] is the longterm sustainability of incentives used in foreest wildfire managment.

\section{Conclusion}

Wildfire situations in Ghana can be successfully controlled and managed by experienced ground crews of fire-fighters, particularly fire volunteers at the local level. The empirical results presented in this paper show that the absence of incentives and lack of insurance serve as disincentives for effective functioning of wildfire squad volunteers around the Tain II Forest Reserve. Volunteers are not insured against wildfires in case of hurts and/or deaths regarding fighting fires. Fire volunteer squads are not well equipped, and, where these equipments are 
available, they are unevenly distributed. This does not allow fire volunteers to give up their best in fighting wildfires. The effort by GNFS to train fire fighting volunteers and involve them in fire combating campaigns is commendable and should be intensified. However, wildfire management activities carried out by various government agencies do not help the current situation of annual wildfires, because it brings with its conflicting implementation strategies and programmes. According to the findings, conflicting implementation strategies and programmes by government agencies are key challenges in planning, implementation and monitoring of wildfire management. In addition to addressing these inter-agency challenges, the study recommends that the District Assembly in collaboration with GNFS provides fire volunteers with basic logistics, food aid and health insurance for their health needs and insurance against fires.

\section{References}

[1] Republic of Ghana (2006) National Wildfire Management Policy. Ministry of Land, Forestry and Mines, Accra.

[2] IUCN (2002) Sustainable Tourism in Protected Areas. IUCN, Gland.

[3] Makarabhirom, P., Ganz, D. and Onprom, S. (2002) Community Involvement in Fire Management: Cases and Recommendations for Community-Based Fire Management in Thailand. In: Moore, P., Ganz, D., Tan, C.L., Enters, T. and Durst, B.P., Eds., Communities in Flames: Proceedings of an International Conference on Community Involvement in Fire Management, RAP Publication 2002/25, FAO Regional Office for Asia and the Pacific, Bangkok, 10-25.

[4] Ganz, D. and Moore, P. (2002) Living with Fire: Summary of Communities in Flames International Conference. In: Moore, P., Ganz, D., Tan, C.L., Enters, T. and Durst, B.P., Eds., Communities in Flames: Proceedings of an International Conference on Community Involvement in Fire Management, FAO Regional Office for Asia and the Pacific, Bangkok, 1-9.

[5] Shield, J.B., Smith, W.R. and Ganz, D. (2006) Fire Management Working Paper: Global Forest Resources Assessment 2005. Report on Fire in the South East Asian (ASEAN) Region, Fire Management Working Paper FFM/10.

[6] Ganz, D., Moore, P.F. and Shields, B.J. (2001). Report of an International Workshop on Community-Based Fire Management. RECOFTC and Project Fire Fight South East Asia, Kasetsart University, Bangkok, 6-8 December 2000, RECOFTC Training and Workshop Report Series, 2001/3 Bangkok.

[7] Moore, F.P. (2003) Community-Based Fire Management (CBFiM). Global Fire Summit, Sydney, 8 October 2003, International Wild Land Fire Summit Paper No. 5.

[8] FAO (2003) Community-Based Fire Management: Case Studies from China, the Gambia, Honduras, India, the Lao People‘s Democratic Republic and Turkey. FAO Regional Office for Asia and the Pacific, Bangkok, RAP Publication 2003/08, Forest Resources Development Service Working Paper FFM/2.

[9] Ganz, D., Moore, P. and Reeb, D. (2003) Prologue: Community-Based Fire Management Case Studies from China, the Gambia, Honduras, India, Lao People‘s Democratic Republic and Turkey. Forest Resources Development Service, Working Paper FFM/2, FAO Regional Office for Asia and the Pacific, Bangkok, RAP Publication 2003/08.

[10] International Forest Fire News (IFFN) (2003) Outcomes of the International Wildland Fire Summit, Sydney, Australia, 8 October 2003. International Forest Fire News (IFFN), July-December 2003, 20-35, No. 29.

[11] Barnes, V.R. (2008) Proposal for Community Fire Management in and around Tain II Forest Reserve in Sunyani Forest District. For Agro-Forestry Practices to Enhance Resource-Poor Livelihood Project (APERL). Faculty of Renewable Natural Resources and Faculty of Forest Resources Technology, KNUST, Kumasi, Unpublished Document.

[12] Obiaw, E. (2004) The National Bushfire Strategy and Wildfire. In: Millar, D., Apusigah, A.A. and Berinyuu, A., Eds., The Chief, the Forestor and the Fireman: Proceedings of the Bushfire Workshop of February 2004, UDS/Care International, Tamale, 51-59.

[13] He, C.C. (2002) Foreword. In: Moore, P., Ganz, D., Tan, C.L., Enters, T. and Durst, B.P., Eds., Communities in Flames: Proceedings of an International Conference on Community Involvement in Fire Management, RAP Publication 2002/25, FAO Regional Office for Asia and the Pacific, Bangkok, 38-56.

[14] Kieft, J. and Nur, A. (2002) Community-Based Disaster Management as a Response to Increase Risk to Disaster with Emphasis on Forest Fire. In: Moore, P., Ganz, D., Tan, C.L., Enters, T. and Durst, B.P., Eds., Communities in Flames: Proceedings of an International Conference on Community Involvement in Fire Management, RAP Publication 2002/25, FAO Regional Office for Asia and the Pacific, Bangkok, 57-73.

[15] Goldammer, G.J., Frost, H.G.P., Jurvelius, M., Kamminga, M.E., Kruger, T., Moody, I.S. and Pogeyed, M. (2002) Community Participation in Integrated Forest Management: Experiences from Africa, Asia and Europe. In: Moore, P., Ganz, D., Tan, C.L., Enters, T. and Durst, B.P., Eds., Communities in Flames: Proceedings of an International Conference on Community Involvement in Fire Management, RAP Publication 2002/25, FAO Regional Office for Asia and the Pacific, Bangkok, 74-91. 
[16] Fire Fight West Africa (2003) Workshop Report on Pre-Project Workshop on Fire Fight, Kumasi, Ghana. Sponsored by International Tropical Timber (ITTO) and Organised by the World Conservation Union (IUCN).

[17] Brody, D.S. (2003) Measuring the Effects of Stakeholder Participation on the Quality of Local Plans Based on the Principles of Collaborative Ecosystem Management. Journal of Planning, Education and Research, 22, 407-419. http://dx.doi.org/10.1177/0739456X03022004007

[18] Grumbine, E. (1994) What Is Ecosystem Management? Conservation Biology, 8, 27-38. http://dx.doi.org/10.1046/j.1523-1739.1994.08010027.x

[19] Westley, F. (1995) Governing Design: The Management of Social Systems and Ecosystems Management. In: Gunderson, L., Holling, C.S. and Light, S.S., Eds., Barriers and Bridges to the Renewal of Ecosystems and Institutions, Columbia University Press, New York, 391-427.

[20] Yaffee, S., Ali, P., Frentz, I., Hardy, P., Maleki, S. and Thorpe, B. (1996) Ecosystem Management in the United States: An Assessment of Current Experience. Island Press, Washington DC.

[21] Duane, T. (1997) Community Participation in Ecosystem Management. Ecology Law Quarterly, 24, 771-797.

[22] Duram, L. and Brown, K. (1999) Assessing Public Participation in U.S. Watershed Planning Initiatives. Society and Natural Resources, 12, 455-467. http://dx.doi.org/10.1080/089419299279533

[23] McCool, S. and Kathleen, G. (2001) Mapping the Dimensions of Successful Public Participation in Messy Natural Resources Management Situations. Society and Natural Resources, 14, 309-323. http://dx.doi.org/10.1080/713847694

[24] Brechin, S.R., West, P., Harmon, D. and Kutay, K. (1991) Resident People and Protected Areas: A Framework for Inquiry. In: West, P. and Brechin, S.R., Eds., Resident Peoples and National Parks: Social Dilemmas and Strategies in International Conservation, The University of Arizona Press, Tucson, 5-28.

[25] Innes, J. (1996) Planning through Consensus Building: A New View of the Comprehensive Planning Ideal. Journal of American Planning Association, 62, 460-472. http://dx.doi.org/10.1080/01944369608975712

[26] Castro, P.A and Nielsen, E. (2001) Indigenous People and Co-Management: Implications for Conflict Management. Environmental Science and Policy, 4, 229-239. http://dx.doi.org/10.1016/S1462-9011(01)00022-3

[27] Orgle, T.K. (2000) Wildfire Management Project in the Transitional Zone of Ghana. Project Document for the Natural Resources Management Programme (NRMP). Royal Netherlands Embassy, and Ministry of Lands and Forestry, Accra.

[28] Amanor, K.S. (2002) Bushfire Management, Culture and Ecological Modernization in Ghana. IDS Bulletin, 33, 65-74. http://dx.doi.org/10.1111/j.1759-5436.2002.tb00008.x

[29] Republic of Ghana (1996) The National Disaster Management Organization (NADMO) Act (Act 517). Ministry of Interior, Accra.

[30] Amissah, L. (2008) Indigenous Fire Management Practices in Ghana. Traditional Forest-Related Knowledge and Sustainable Forest Management in Africa. IUFRO World Series Vol. 23.

[31] Environmental Protection Agency (EPA) (2002) National Action Programme to Combat Drought and Desertification. EPA, Accra.

[32] Hall, J.B. and Swaine, M.D. (1981) Distribution and Ecology of Vascular Plants in a Tropical Rain Forest: Forest Vegetation in Ghana. W. Junk, The Hague. http://dx.doi.org/10.1007/978-94-009-8650-3

[33] Adhikari, R.J. (2001) Community-Based Natural Resource Management in Nepal with Reference to Community Forestry: A Gender Perspective. Journal of the Environment, 6, 9-22.

[34] FAO (2007) Fire Management—Global Assessment 2006. A Thematic Study Prepared in the Framework of the Global Forest Resources Assessment 2005. FAO Forestry Paper 151, Rome.

[35] FAO (2009) Forest Fires and the Law: A Guide for National Drafters Based on the Fire Management Voluntary Guidelines. FAO Legislative Study 99. www.fao.org/docrep/011/i0488e/i0488e00.htm

[36] McCay, B.J. and Jentoft, S. (1998) Market or Community Failure? Critical Perspectives on Common Property Research. Human Organization, 57, 21-29. http://dx.doi.org/10.17730/humo.57.1.372712415k227u25

[37] Zhang, L.C., Wu, L., Zhao, Y.Q. and Lu, C.Z. (2003) Community-Based Forest Fire Management in Wenyime Village, Sanchahe Township, Dayao Country, Chuxiong Yi Autonomous Prefecture. Forest Resources Development Service, Working Paper FFM/2. RAP Publication 2003/08. FAO Regional Office for Asia and the Pacific, Bangkok.

[38] Dampha, A. (2003) Management of Forest Fires through the Involvement of Local Communities: The Gambia. Forest Resources Development Service, Working Paper FFM/2. RAP Publication 2003/08. FAO Regional Office for Asia and the Pacific, Bangkok.

[39] Alvarado, A.C., Rosales, E.S. and Aguilar, S.A.M. (2003) Management of Forest Fires and the Participation of Local Communities. Forest Resources Development Service, Working Paper FFM/2. RAP Publication 2003/08. FAO Re- 
gional Office for Asia and the Pacific, Bangkok.

[40] Nanda, K.P. and Sutar, C.P. (2003) Management of Forest through Local Communities: A Study in the Bolangir, Deogarh and Sundergarh Districts of Orissa, India. Forest Resources Development Service, Working Paper FFM/2. RAP Publication 2003/08. FAO Regional Office for Asia and the Pacific, Bangkok.

[41] London, S. (2003) Community-Based Fire Management in Lao People’s Democratic Republic: Past, Present and Future. Forest Resources Development Service, Working Paper FFM/2. RAP Publication 2003/08. FAO Regional Office for Asia and the Pacific, Bangkok.

[42] Kurtulmuslu, M. and Yazici, E. (2003) Management of Forest Fires through the Involvement of Local Communities in Turkey. Forest Resources Development Service, Working Paper FFM/2. RAP Publication 2003/08. FAO Regional Office for Asia and the Pacific, Bangkok. 